\title{
黒鉛ヒーターの高温電気抵抗
}

岡田雅樹

(平成 4 年 10 月 20 日受理)

\section{Electric resistance of graphite heater at high temperatures.}

\author{
Masaki Okada \\ TOYO TANSO CO., LTD \\ 2181-2, Nakahime, Ohnohara-cho, Mitoyo-gun, \\ Kagawa-ken 769-16, Japan
}

\begin{abstract}
Electric resistance of heaters made of isotropic graphite, IG-11, was measured in the temperature range from room temperature to $3000^{\circ} \mathrm{C}$ in argon atmosphere. Four heaters with different sizes were set in four furnaces, being installed with different capacities of electric sources $1900 \mathrm{~A} \times 10.5 \mathrm{~V}, 2700 \mathrm{~A} \times 20 \mathrm{~V}$ and $3500 \mathrm{~A} \times 24 \mathrm{~V}$. The increase of resistance with temperature rise from about $1000^{\circ} \mathrm{C}$ to $3000^{\circ} \mathrm{C}$ was observed for the heaters whose applied voltage was $10 \mathrm{~V}$, whereas remarkable decrease of resistance above $2500^{\circ} \mathrm{C}$ appeared for two other heaters applied $12 \mathrm{~V}$. It was found that the temperature dependence of electric resistance of graphite heater is influenced by not only graphite material and gas atmosphere but also the matching between heater size and capacity of power source.
\end{abstract}

KEYWORDS: Electric resistivity, Isotropic graphite, Temperature dependence

\section{1. 緒言}

黒鉛材料は， $3000^{\circ} \mathrm{C}$ 以上の耐熱性を持ち, 輻射率が高 く，また機械加工性に優れ，大型材料の製造が可能であ ク, しかも比較的に安価であることから, 高温 (1300ํ以上)炉のヒーター, サセプターおよび炉内構造 物として使用されている。

黑鉛材料の電気抵抗率は温度の関数であるため, 工業 炉のヒーターとして使用する場合その温度依存性を知る ことは, 炉の電源を設計する上で極めて重要である。高 温での黒鉛ヒーターの抵抗值の適切な評価を誤ると, 用 意した電源の電圧および電流の制限値から黑鉛ヒーター に電力を十分入力できないことになり, 所望温度が得ら

東洋炭素(株)： $7769-16$ 香川県三豊郡大野原町中姫 2181-2
れないことが起こりうる。例えば，高温における黒鉛 ヒーターの抵抗值が評価值より高い場合，(1)式から明ら かなように初期電圧より高い電圧を掛けなければならな い。

$$
\mathrm{W}=\mathrm{V}_{\mathrm{e}} \times \mathrm{I}_{\mathrm{e}} \times \cos \varphi
$$

ここで, Wは電力, $\mathrm{V}_{\mathrm{e}}$ は実効電圧, $\mathrm{I}_{\mathrm{e}}$ は実効電流および $\cos \varphi$ は力率(ここでは 1 とする)である。その電圧が電源 電圧の容量值(最大値)を超える場合は, 必要な電流を流 すことができず，投入電力が不足して所望の温度が得ら れないことになる。また, 逆にヒーターの抵抗值が評価 值より低い場合, 低い電圧で大きな電流が流れる。した がって, 電源の電流の容量値を与える電圧が相対的に低 くなり, 投入電力が不足して, これまた所望の温度が得 られないことになる。

コークスをベースとした人造黒鉛材料の電気抵抗率は, 
温度の上昇とともに一度低下した $\left(500^{\circ} \mathrm{C}\right.$ 付近 $)$ 後, 単調 に増加すると考えられてきた1)-5)。しかし，足立ら6)は高 純度化した等方性・高密度黒鉛IG-11の抵抗率をアルコ ン雲囲気中で測定した場合，900K $\left(627^{\circ} \mathrm{C}\right)$ から $2300 \mathrm{~K}$ $\left(2027^{\circ} \mathrm{C}\right)$ までの温度域では増加し， $2400 \mathrm{~K}\left(2127^{\circ} \mathrm{C}\right)$ 以上 では低下すること，さらに昇・降温のくり返しによって $2400 \mathrm{~K}\left(2127^{\circ} \mathrm{C}\right)$ 以上での減少量が少なくなることを報告 した。またここの減少は窒素ガス雲囲気中では起こらな いことも報告している。これに対して，松崎ら7は窒素 ガス雲囲気中でも $2200^{\circ} \mathrm{C}$ 以上の高温域で抵抗率の減少が

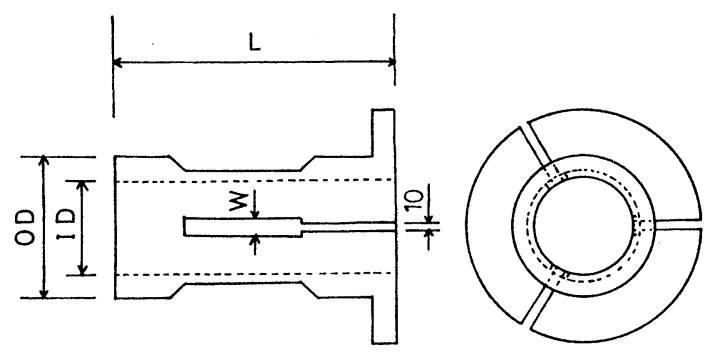

\begin{tabular}{c|c|c|c|c}
\hline & $L(\mathrm{~mm})$ & $O D(\mathrm{~mm})$ & $1 \mathrm{D}(\mathrm{mm})$ & $W(\mathrm{~mm})$ \\
\hline No. 1 & 430 & 200 & 150 & 20 \\
\hline No. 2 & 730 & 440 & 400 & 10 \\
\hline No. 3 & 670 & 320 & 290 & 10 \\
\hline No. 4 & 730 & 380 & 350 & 10 \\
\hline
\end{tabular}

Fig.1 Test specimens made of the graphite block IG-11.
認められると報告した。逆に，佐藤ら ${ }^{8)}$ は，10種の黒鉛

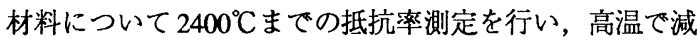
少する傾向が認められなかったと報告している。

そこで，本報告では等方性・高密度黒鉛IG-11を用い て大きさの異なるヒーターを製作し，電源容量の異なる 4 式の $3000^{\circ} \mathrm{C}$ ま゙昇温可能な炬に設置して，それらの電 気抵抗值を温度の関数として测定することにより電源容 量を考虑した黒鉛ヒーターの電気抵抗の温度依存性を論 ビこととした。

\section{2. 実 験}

等方性・高密度黒鉛IG-11ブロックより Fig.1に示すよ うな寸法の異なる4種の円筒状ヒーターを切り出した。 No. 1 とNo.2のヒーターの 2 つの端子間に直流電流を流し て電圧降下法により求めた各エレメントの抵抗值はいづ

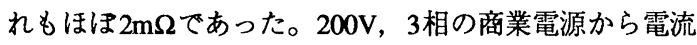
調整器, 変圧器および銅電極を経て, 黒鉛ヒーターに電 力を投入できるようになっている。アルゴンガス雲囲気 (微小な正圧) 中で $0.2 \sim 0.3 \mathrm{~K} \cdot \mathrm{s}^{-1}$ の昇温速度で炉を昇温し ながら, ヒーターの温度の関数として変圧器の二次側の 電圧，電流を測定した。測温は，低温では熱電対を，高 温ではパイロメーターを用いて行った。電源ならびに炉 の構成を模式的にFig.2に示した。なお，ヒーターは断 熱材で囲まれており，水冷銅電極との接続は断熱材の外 側でなされている。また，ヒーターNo.1用に使用した変 圧器の電源容量は $1900 \mathrm{~A}, 10.5 \mathrm{~V}$ ありり No.2およびNo.3 用はそれぞれ 2700A，20Vであり，No.4 用はそれぞれ 3500A，24Vであった。

二次側の電圧計の読み值を電流計の読み值と $\sqrt{3}$ との 積で除した值をヒーターの「抵抗值」とした。

No.1 とNo.2のヒーターを使った炉では室温における

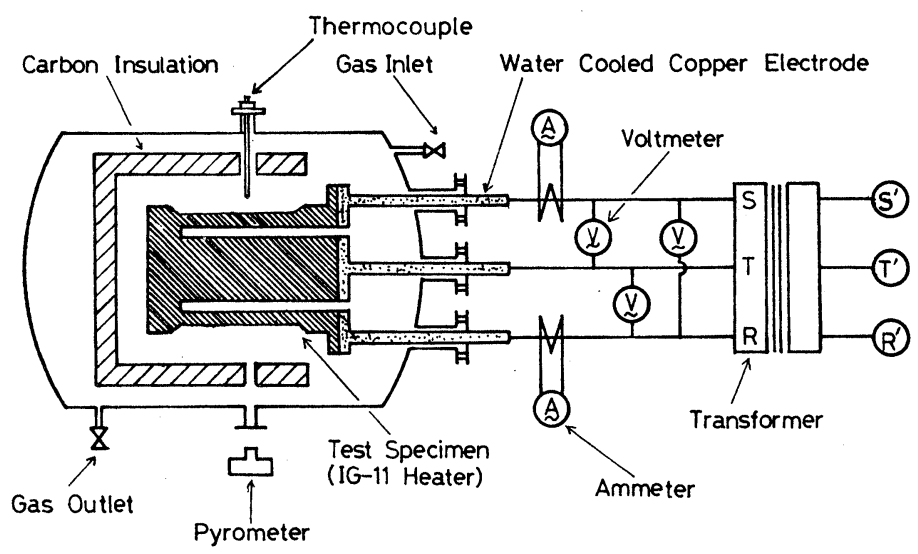

Fig.2 Schematics of the furnace for electric resistance measurement. 

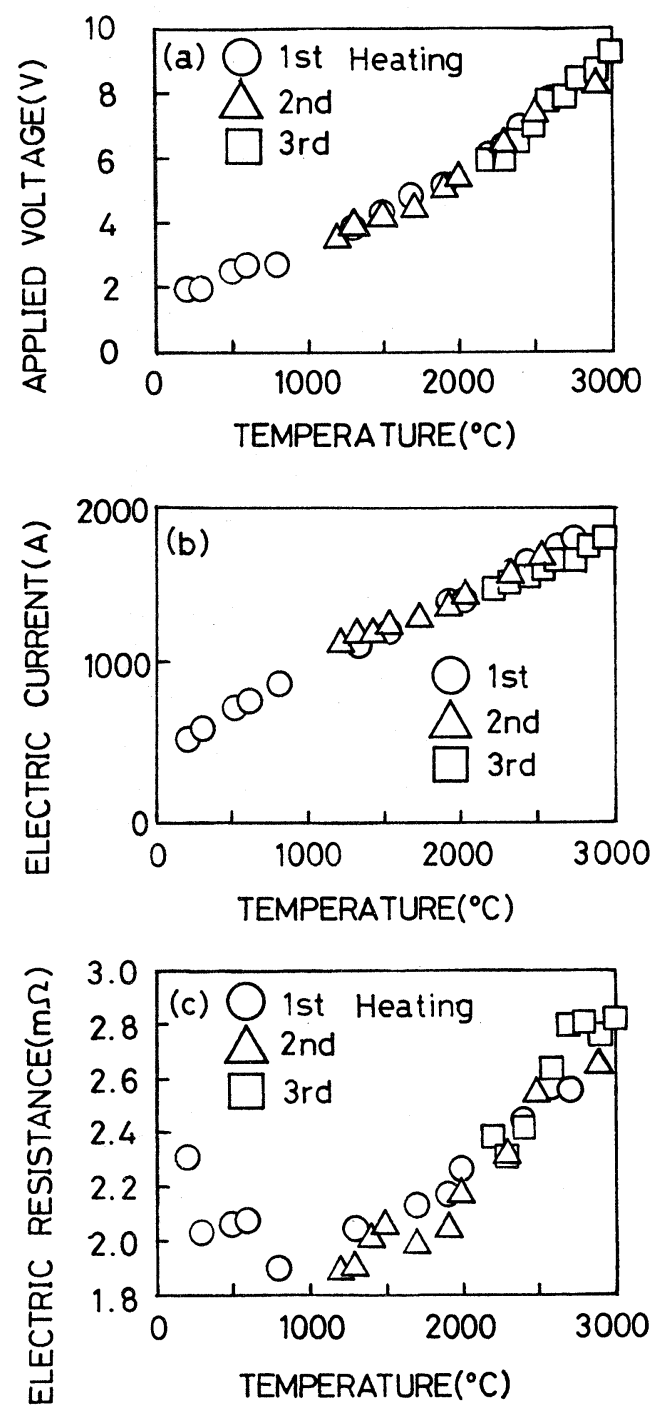

Fig.3 Values applied voltage(a), electric current(b) and electric resistance(c) plotted as function of temperature and measured for the graphite heater No.1(see Fig.1) using the furnace with the capacity of the power source of $1900 \mathrm{~A} \times 10.5 \mathrm{~V}$. Three cycles of the measurements were carried out only during heating up.

この「抵抗值」がほぼヒーター単体の抵抗 $2 \mathrm{~m} \Omega に 一$ 致し た。それゆえ，二次側の電圧，電流值から計算した「抵 抗值」に対して，銅電極および銅線の影響は無視し得る と考えられた。

\section{3. 結果と考察}

黒鉛ヒーターNo.1 および No.2 についての測定結果 を，ヒーターの温度に対して抵抗值，印加電圧および一 相に流れる電流をプロットすることによってそれぞれ

Fig.3およびFig.4に示した。

ヒーターNo.1では3回の昇降温を繰り返した場合の昇 温中の測定值を Fig.3に示した。各相ともほほ同じ電 圧，電流值を示した(Fig.4参照)のでFig.3では一相の測 定結果のみ示した。ヒーターNo.2では一回の昇温試験を 行って，端子 $\mathrm{T}$ Sおよび $\mathrm{T}$ と間で測定した電圧值を， また端子RおよびSで測定した電流值をそれぞれ区別し て温度に対してプロットした〔Fig.4(a)および(b)]。さ らに抵抗値については端子Tに対する他の 2 端子Rおよ びSの間で測定した結果をプロットした〔Fig.4(c)]。 ヒーターNo.1においては, 抵抗值は温度の上昇とともに 一度低下した後単調に増加している。そして $2400^{\circ} \mathrm{C}$ 以上 となっても抵抗值は上昇した。この抵抗值の温度依存性 は繰り返しの測定でほほ同一線上に載り，良い再現性を 示した。足立ら ${ }^{6)}$ の指摘した繰り返しによる抵抗值変化 は認められなかった。これに対して，ヒーターNo.2では $2200^{\circ} \mathrm{C}$ 以上で抵抗值は下がり始め, $2500^{\circ} \mathrm{C}$ 以上では急激 な減少を示した。なお $2000^{\circ} \mathrm{C}$ 付近の電流・電圧值の乱れ は昇温速度を変えたために温度制御がスムーズに進行し なかったためである。 $2000^{\circ} \mathrm{C}$ 以下以上では電圧と電流 の関係が変化しており， $2000^{\circ} \mathrm{C}$ 以上では電圧の上昇によ り大きい率で電流が増大し抵抗值の降下が観測された。 各端子の間の電圧，各端子の電流は全く一致している。 抵抗值も一致しており， $2200^{\circ} \mathrm{C}$ 以上でいずれの端子間の 抵抗值も減少していることがわかる。本実験の結果は, 全く同一材質の黒鉛材料を用いながら，その抵抗の温度 依存性が大きく異なることを示している。そして足立ら6) の結果と合わせてみると，黒鉛材料の高温抵抗率は，(1) 雲囲気ガス(アルゴン, 窒素), (2)脱ガス状態(繰り返し 測定)に加えて (3)測定体の形状，炉の構造および(4)電源 の容量などの因子を考えるべきであろう。

ヒーターNo.2で観測された電圧・電流の関係の変化, すなわち抵抗值の温度依存性の変化が高温で回路の短絡 が生じたためと考えられた。そこでNo.2 と同様に $2200^{\circ} \mathrm{C}$ 以上で抵抗值の減少が認められたNo.3のヒーター につけたスリットの幅(Fig.1中のW)を 10mmから 50mm にと大きくしたが, やはり $2200^{\circ} \mathrm{C}$ 以上で抵抗值の減少が 認められた。かえって減少開始温度が低くなった。

足立ら ${ }^{6}$ は高純度処理した黒鉛材料 IG-110を試験片と して使っている。IG-110は高純度処理していないIG-11 に比へ, $\mathrm{H}_{2}, \mathrm{CO}, \mathrm{H}_{2} \mathrm{O}, \mathrm{CO}_{2}$, 炭化水素等の吸着ガスが少 

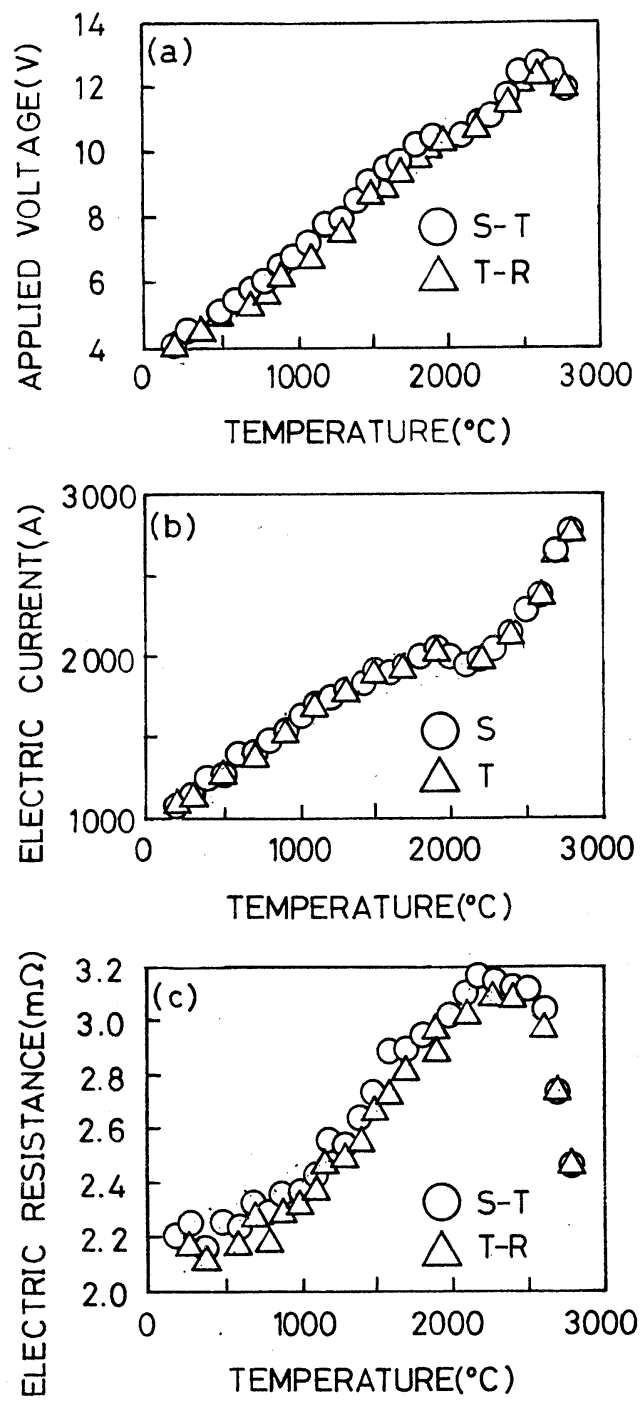

Fig.4 Values applied voltage(a), electric current(b) and electric resistance(c) plotted as function of temperature and measured for the graphite heater No.2(see Fig.2) using the furnace with the capacity of the power source of $2700 \mathrm{~A} \times 20 \mathrm{~V}$. The values measured for the two different pairs of heater terminals $(S-T$ and T-R,see Fig.2) were plotted.

なく9)，しかも足立ら6)が用いた試験片は小さく, 測定の ため昇温による脱ガスが効果的に生じていることが考え
られる。本実験のヒーターNo.1は高純度処理をしていな いIG-11を用い, 試験片としたヒーターの体積も大きい ことから昇降温を繰り返しても必ずしも脱ガスができて いないことが考えられる。そのため，足立らの結果では 繰り返しによる抵抗率の変化が観測され，本実験ではさ れなかったと考えられる。

ヒーターNo.1 とヒーターNo.2 に印加された電圧值 〔Fig.3(a)および4(a)〕を比較してみるとヒーターNo.2

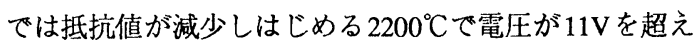
ているのに対してNo.1では10V以下である。減圧下でア ルゴンガス雲囲気中では放電を起こしやすいことが知ら れている。そこで, 印加電圧が高いとみかけ上抵抗值が 下がるようにも考えられる。しかし，No.4のヒーターで は $24 \mathrm{~V}, 3500 \mathrm{~A}$ の容量の電源を使った場合, $18.0 \mathrm{~V}$,

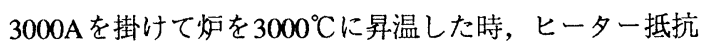
值は温度ともに単調に増加した。したがって, 単に印加 電圧が高いと高温で抵抗值が下がるわけでもない。ヒー ター形状, 炬の構造, 電源とのマッチングがヒーターの 抵抗值に影響すると考えるのが妥当であろう。

\section{謝辞}

本原稿を書くあたり多くのご助言を賜りました北海道 大学工学部稲垣道夫教授に御礼申し上げる。

\section{文献}

1) 石川敏功, 長沖 通, 新 - 炭素工業 (1980), P41, 近 代編集社。

2) A. I. Lutcov, V. I. Volga and B. K. Dymov, Carbon 8 (1970) 753-760.

3) S. G. Bapat and H. Nickel, Carbon 11 (1973) 323327.

4) S. G. Bapat, Carbon 11 (1973) 511-514.

5) 水島三知, 炭素 1959 [No.7] 2-5.

6) 足立正和, 塩山 洋, 成澤雅紀, 池田 茂, 辰巳国 昭, 相馬 熏, 磯崎秀夫, 江川和則, 久德博文, 田 邦村武司, 炭素 1991 [No.146] 33-36.

7) 松崎弘和, 玉田興史, 日本学術振興会 第117委員 会資料 117-216-B-1 (1991).

8）佐藤千之助, 佐々木哲也, 車田 亮, 川又清広, 柴 野正順, 日本学術振興会 第117委員会資料 117218-B-4 (1992).

9) 岡田雅樹, 福田 伸, 山科俊郎, 炭素 1992 [No.153] 176-183. 